\title{
PENGEMBANGAN BAHAN AJAR DENGAN MODEL MIND MAP UNTUK PEMBELAJARAN ILMU PENGETAHUAN SOSIAL SMP
}

\author{
Lukman, Ishartiwi \\ Program Studi Teknologi Pembelajaran PPs UNY, Universitas Negeri Yogyakarta \\ $\underline{\text { lux_sains@yahoo.co.id, buisyk@yahoo.com }}$
}

\begin{abstract}
Abstrak
Penelitian ini bertujuan untuk menghasilkan bahan ajar dengan model mind map yang layak digunakan pada pembelajaran Ilmu Pengetahuan Sosial (IPS) untuk siswa SMP, serta mengetahui keefektifan bahan ajar hasil pengembangan. Penelitian ini merupakan penelitian dan pengembangan (Research and Development). Hasil penelitian adalah sebagi berikut: (1) menghasilkan bahan ajar dengan model mind map untuk pembelajaran Ilmu Pengetahuan Sosial siswa SMP yang dikemas dalam bentuk buku dengan materi "Perkembangan pada Masa Islam di Indonesia". Produk yang dihasilkan layak digunakan untuk pembelajaran berdasarkan validasi dari ahli materi, ahli media, uji coba terbatas, serta uji coba lapangan. (2) Bahan ajar hasil pengembangan untuk siswa kelas VII di SMP N 3 Berbah ini efektif digunakan untuk pembelajaran IPS. Peningkatan skor postes pada kelas yang menggunakan bahan ajar dengan model mind map sebesar $13,87 \%$ dengan nilai gain score 0,45 dan ketuntasan siswa 100\%. Sedangkan kelas yang menggunakan buku paket IPS dengan peningkatan skor postes sebesar $10,26 \%$ dengan nilai gain score 0,35 dan ketuntasan siswa $87,1 \%$.
\end{abstract}

Kata kunci: bahan ajar, mind map, ilmu pengetahuan sosial

\section{DEVELOPING AN INSTUCTIONAL MATERIAL USING MIND MAP MODEL FOR LEARNING SOCIAL SCIENCES FOR JUNIOR HIGH SCHOOL}

\author{
Lukman, Ishartiwi \\ Program Studi Teknologi Pembelajaran PPs UNY, Universitas Negeri Yogyakarta \\ lux_sains@yahoo.co.id, buisyk@yahoo.com
}

\begin{abstract}
This study aims to produce an instructional material with the model mind map which is feasible for use in teaching Social Studies (IPS) for Junior High School students, and to investigate the effectiveness of instructional material development results. This study was a research and development $(R \& D)$. The results of the study as follows: (1) Producing an instructional material with the model mind map for learning Social Science junior high school students in the form of a book that is packed with material "Developments in Indonesian Islamic Period". The result product is feasible for learning based on validation materials experts, media experts, small-scale field tryout, and field tryout. (2) An instructional material for the development of class VII in SMP N 3 Berbah effectively increased students' understanding of concepts. Increase in posttest scores on the class using instructional materials with the model mind map is of $13.87 \%$ with a gain score of 0.45 and $100 \%$ student mastery, while the class using Social Science textbooks with posttest scores increased by 10.26\% with the gain score of 0.35 and $87.1 \%$ student mastery.
\end{abstract}

Keywords: instructional materials, mind map, social science 


\section{Pendahuluan}

IPS merupakan salah satu mata pelajaran yang dipelajari di Sekolah Menengah Pertama (SMP) yang harus dikuasai kompetensinya oleh siswa. Mata pelajaran IPS merupakan mata pelajaran di tingkat sekolah dasar dan menengah yang identik dengan istilah social studies (Sapriya, 2011, p.19). Dalam kajiannya, IPS melibatkan berbagai disiplin ilmu baik di dalam maupun di luar disiplin ilmu-ilmu sosial. Kajian dari mata pelajaran IPS merupakan studi terintegrasi dari ilmu-ilmu sosial dan humaniora. Integrasi antar bidang kajian dalam IPS merupakan ciri khas mata pelajaran IPS. Sedangkan, karakteristik proses pembelajaran IPS disesuaikan dengan karakteristik kompetensi.

Kendala yang dihadapi dalam proses pembelajaran IPS yaitu kurangnya bahan ajar yang menarik untuk siswa. Bahan ajar yang digunakan hanya berupa textbook dalam mengajar. Buku yang digunakan dalam pembelajaran masih bersifat naratif dalam menjelaskan isi materi. Sehingga menyebabkan siswa merasa kesulitan dalam memahami materi IPS. Peran bahan ajar sangat penting dalam proses pembelajaran. Jika sumber belajar dan bahan ajar kurang menarik atau terkesan monoton, maka akan menurunkan kualitas pembelajaran sehingga pemahaman siswa tentang materi yang diajarkan menjadi terhambat. Bahan ajar yang masih naratif tentu tidak menarik dan akan menyulitkan siswa dalam pembelajarannya.

Berkenaan dengan itu perlu adanya bahan ajar yang dapat membantu peserta didik dalam memahami materi dengan lebih efektif dan efisien. Salah satu cara yang dapat digunakan untuk meningkatkan pemahaman siswa terhadap materi yang dipelajari yaitu dengan menggunakan metode mind mapping. Buzan (1996, p.60) mengungkapkan bahwa mind map dapat membantu dalam menyimpan memori seseorang secara efisien. Sedangkan de Porter (2011, p.152) mengungkapkan bahwa dalam menggunakan mind map, siswa dapat belajar dengan mengunakan dua belahan otaknya secara sinergis. Berpikir sinergis mengaktifkan semua fungsi dua bagian otak sekaligus, itulah tujuan mind map karena mind map mengandung unsur-unsur warna, simbol, dan gambar yang menarik.

Konsep mind map telah lama digunakan dalam proses pembelajaran. Dengan menggunakan konsep mind map, guru dapat menyampaikan materi pelajaran yang rumit dengan mudah. Selain itu, siswa dapat menyerap materi pembelajaran lebih mudah karena disampaikan dengan cara yang sederhana (Saleh, 2008, p.76). Dengan demikian pembelajaran dengan menggunakan mind map menjadi lebih efektif.

Dipilihnya mind map sebagai model desain penyampaian pesan karena mind map dapat membantu siswa dalam belajar, mengatur serta menyimpan sebanyak mungkin informasi yang diinginkan oleh siswa (Buzan, 2005, p.13). Selain itu mind map praktis dan mudah dalam pengembanganya karena tidak membutuhkan keterampilan yang rumit. Oleh karena itu, guru dan siswa dapat dengan mudah mengembangkannya.

Pengembangan bahan ajar yang memenuhi aspek-aspek pembelajaran serta pemilihan media pembelajaran yang tepat digunakan dalam pembelajaran telah dibahas dalam salah satu bidang ilmu yaitu bidang instructional technology. Definisi Teknologi Pembelajaran yang dirumuskan oleh Association for Educational Communications And Technology (AECT) (2004, p.3) "Educational technology is the study and ethical practice of facilitating learning and improving performance by creating, using, and managing appropriate technological processes and resources".

Definisi teknologi pembelajaran tahun 2004 ini mengandung maksud bahwa teknologi pembelajaran mempunyai peran untuk memfasilitasi pembelajaran dan meningkatkan kinerja dengan cara menciptakan, menggunakan atau memanfaatkan dan mengelola proses dan sumbersumber teknologi yang tepat. Mengingat bahwa objek teknologi pendidikan adalah 
belajar manusia, maka akhir-akhir ini istilah teknologi pendidikan cenderung digantikan dengan teknologi pembelajaran (Miarso, 2004, p.168).

Salah satu bidang garapan dalam Teknologi Pembelajaran yaitu mengembangkan bahan ajar yang tepat guna sesuai dengan kebutuhan. Dalam kaitannya dengan pengembangan bahan ajar, maka tujuan yang hendak dicapai oleh teknologi pembelajaran sesuai dengan komponen "creating" dalam defisini teknologi pembelajaran di atas, yaitu memfasilitasi pembelajaran. Definisi menurut AECT sebelumnya, yaitu tahun 1994 menggunakan istilah desain, pengembangan, dan evaluasi untuk merujuk pada fungsi "creating" pada sumbersumber belajar (Januszewski \& Molenda, 2008, p.49).

Berdasarkan bidang Teknologi Pembelajaran di atas, maka cakupan dari Teknologi Pembelajaran salah satunya yaitu menciptakan bahan ajar yang tepat guna sesuai dengan kebutuhan siswa. Dalam pembelajaran di sekolah, guru hendaknya selalu berinovasi dalam menciptakan pembelajaran yang inovatif melalui pengembangan bahan ajar sebagai media yang dapat digunakan dalam proses pembelajaran. Upaya pengembangan bahan ajar sebagai media dalam proses pembelajaran penting untuk dilakukan guna mewujudkan pembelajaran yang efektif dan efisien. Sehingga kompetensi yang harus dicapai oleh siswa dapat dikuasai.

Pengembangan bahan ajar dengan model mind map merupakan solusi alternatif sebagai pemanfaatan sumber belajar yang dapat digunakan oleh siswa sebagai bahan materi pembelajaran. Sajian bahan ajar sebagai bentuk pemanfaatan media pembelajaran yang tepat digunakan sesuai dengan kebutuhan siswa.

Berdasarkan latar belakang, maka rumusan masalah dalam penelitian ini yaitu: (1) menghasilkan bahan ajar dengan model mind map yang layak digunakan pada pembelajaran IPS untuk siswa SMP; dan (2) keefektifan bahan ajar hasil pengembangan yang digunakan pada pembelajaran IPS.
Dari urauian tersebut, tujuan penelitian ini adalah: (1) menghasilkan bahan ajar dengan model mind map yang layak digunakan pada pembelajaran IPS untuk siswa SMP serta (2) mengetahui bagaimanakah keefektifan bahan ajar hasil pengembangan yang digunakan pada pembelajaran IPS.

\section{Metode Penelitian}

Jenis Penelitian

Pengembangan bahan ajar dengan model mind map termasuk Research and Development (R \& D). Penelitian ini bertujuan untuk mengembangkan produk pembelajaran berupa media cetak dalam mata pelajaran IPS untuk SMP.

\section{Model Pengembangan}

Model prosedural yang dipakai mengacu pada langkah-langkah yang telah dikembangkan oleh Borg \& Gall (1983, p.775) yaitu: (1) penelitian pendahuluan dan pengumpulan informasi, (2) perencanaan, (3) pengembangan produk awal, (4) uji coba lapangan awal, (5) revisi produk awal, (6) uji coba lapangan, (7) revisi produk utama, (8) produk akhir.

\section{Prosedur Pengembangan}

Prosedur pengembangan bahan ajar dalam penelitian ini dapat dijelaskan dalam gambar berikut:

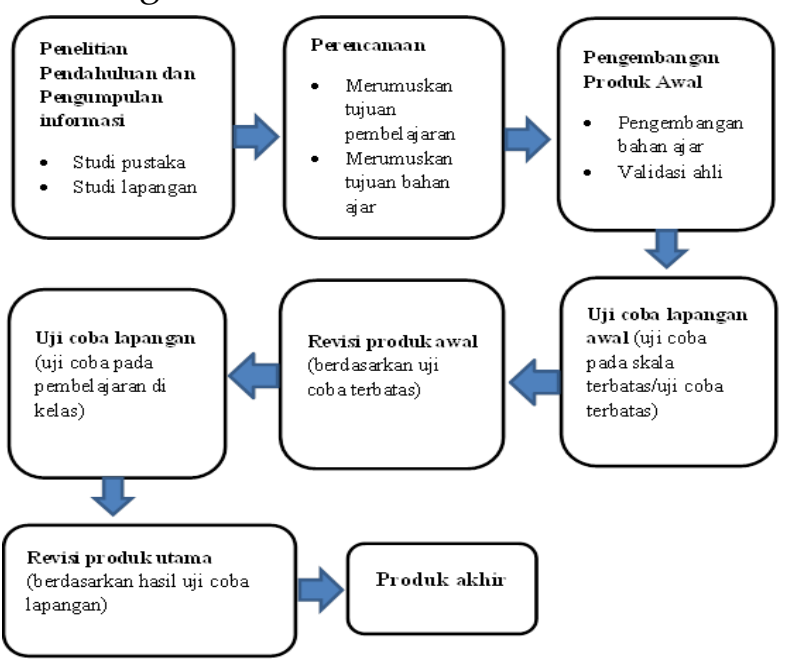

Gambar 1. Prosedur Pengembangan Bahan Ajar 


\section{Desain Uji Coba}

Uji coba produk sebagai bagian dari tahap pengembangan dilakukan dengan dua tahap yaitu uji coba pertama (uji coba terbatas) dan uji coba kedua (uji coba lapangan). Uji coba terbatas dilakukan untuk mengetahui pendapat siswa dalam skala kecil mengenai produk bahan ajar yang dihasilkan. Hasil uji kelompok kecil ini akan dijadikan masukan untuk perbaikan produk akhir. Hasil revisi inilah yang kemudian digunakan dalam uji coba lapangan. Uji coba lapangan menggunakan desain penelitian Pretest-Posttest Group Design untuk mengetahui nilai gain score masing-masing kelompok uji coba.

\section{Subjek Coba}

Subjek uji coba dalam penelitian ini yaitu siswa SMP N 3 Berbah Kabupaten Sleman kelas VII semester 2 Tahun Ajaran 2012/2013. Adapun pembagiannya yaitu uji coba terbatas sebanyak 9 siswa, subjek uji coba lapangan yaitu kelas VII C dengan jumlah 31 siswa (kelompok yang menggunakan bahan ajar dengan model mind map) dan kelas VII B dengan jumlah 31 siswa (kelompok yang menggunakan buku paket IPS).

\section{Jenis Data}

Jenis yang digunakan dalam penelitian pengembangan ini adalah data kuantitatif dan kualitatif yang kemudian dianalisis secara statistik deskriptif. Data kuantitatif diperoleh dari hasil angket yang berupa skor penilaian dari ahli materi, ahli media dan siswa dengan menggunakan skala 4 dengan rentang nilai: 4 untuk kategori sangat baik, 3 untuk kategori baik, 2 untuk kategori cukup baik, dan 1 untuk kategori kurang baik. Data kuantitatif juga diperoleh dari skor hasil pretes dan postes.

Data kemudian dideskripsikan sebagai bahan pertimbangan untuk merevisi produk hasil pengembangan. Data kuantitatif dan kualitatif tersebut diperlukan untuk melihat kualitas dari bahan ajar agar dapat digunakan dalam proses pembelajaran.

\section{Instrumen Pengumpulan Data}

Instrumen yang digunakan sebagai pengumpul data berupa lembar angket untuk ahli materi, ahli media, siswa dan soal pretes dan postes. Angket digunakan untuk mengetahui kelayakan produk bahan ajar yang dikembangkan dari aspek kelayakan isi, materi, penyajian, kebahasaan, kegrafikan. Sedangkan soal digunakan untuk mengetahui ketuntasan belajar siswa pada pembelajaran IPS di kelas.

\section{Teknik Analisis Data}

Teknik analisis data kelayakan bahan ajar menggunakan skala likert. Skor yang diperoleh kemudian dikonversikan menjadi nilai dengan skala 4, yaitu membagi nilai standar menjadi empat skala atau empat kualifikasi. Skala 4 dalam teknik statistik penelitian dan pengembangan ini yaitu $A=$ sangat baik, angka $B=$ baik, angka $\mathrm{C}=$ cukup baik, angka $\mathrm{D}=$ kurang baik. Untuk mengetahui kualitas bahan ajar hasil pengembangan baik dari aspek materi maupun aspek media, serta untuk mengetahui respon siswa terhadap bahan ajar, maka dari data yang mula-mula berupa skor, diubah menjadi data kualitatif dengan skala empat. Adapun acuan pengubahan skor menjadi skala empat sebagai berikut:

Tabel 1. Konversi Skor pada Skala 4

\begin{tabular}{ccc}
\hline Nilai & Interval & Kategori \\
\hline $\mathrm{A}$ & $\mathrm{Mi}+1,5 \mathrm{SDi} \leq \mathrm{X} \leq \mathrm{Mi}+3,0 \mathrm{Sdi}$ & Sangat Baik \\
$\mathrm{B}$ & $\mathrm{Mi}+0 \mathrm{SDi} \leq \mathrm{X}<\mathrm{Mi}+1,5 \mathrm{Sdi}$ & Baik \\
$\mathrm{C}$ & $\mathrm{Mi}-1,5 \mathrm{SDi} \leq \mathrm{X}<\mathrm{Mi}+0 \mathrm{Sdi}$ & Cukup Baik \\
$\mathrm{D}$ & $\mathrm{Mi}-3 \mathrm{SDi} \leq \mathrm{X}<\mathrm{Mi}-1,5 \mathrm{Sdi}$ & Kurang baik \\
\hline
\end{tabular}

Sedangkan teknik analisis data untuk melihat keefektifan penggunaan produk hasil pengembangan dengan melihat nilai gain score dan persentase kelulusan siswa. Nilai gain score pada kelompok yang menggunakan buku paket IPS dengan kelompok yang menggunakan bahan ajar model mind map yang bertujuan mengetahui skor siswa dengan melihat perolehan skor gain. Peningkatan yang terjadi sebelum kegiatan pembelajaran menggunakan bahan ajar dengan model mind map dan 
sesudah pembelajaran menggunakan bahan ajar dengan model mind map diperhitungkan dengan rumus $N$-gain yang ditentukan berdasarkan rata-rata gain skor yang dinormalisasi (g) yaitu perbandingan dari skor gain. Rata-rata gain yang dinormalisasi (N-gain) (Hake, 1998, p.2) dinyatakan oleh persamaan sebagai berikut:

$$
g=\frac{S \text { post }- \text { S pre }}{\text { S maks }- \text { S pre }}
$$

keterangan:

$S$ post : Rata-rata Skor Postes

$S$ pre : Rata-rata Skor Pretes

$S$ maks: Skor Maksimal

Interpretasi ke dalam tabel klasifikasi nilai Gain (Hake, 1998,p.3) berikut:

Tabel 2. Interpretasi Nilai Gain

\begin{tabular}{cc}
\hline Nilai $(\mathrm{g})$ & Klasifikasi \\
\hline$(\mathrm{N}$-gain $) \geq 0,7$ & Tinggi \\
$0,7>(\mathrm{N}$-gain $) \geq 0,3$ & Sedang \\
$(\mathrm{N}$-gain $)<0,3$ & Rendah \\
\hline
\end{tabular}

\section{Hasil Penelitian dan Pembahasan}

Hasil Penelitian pendahuluan

Kegiatan penelitian dan pengumpulan informasi merupakan kegiatan mengumpulkan dan menganalisis data dari sekolah mengenai bahan ajar atau media dalam rangka untuk mengembangkan produk yang akan dihasilkan. Kegiatan ini dilakukan untuk mengetahui kebutuhan siswa dan guru tentang materi atau pokok bahasan dalam mata pelajaran IPS yang dirasakan perlu mendapatkan bantuan untuk dibuatkan media dan jenis media yang seperti apa yang paling cocok atau paling sesuai untuk dikembangan melalui penelitian ini. Penelitian pendahuluan ini dilakukan dengan cara peninjauan ke sekolah dan wawancara langsung dengan guru mata pelajaran IPS. Informasi-informasi yang didapat tersebut dibutuhkan dan digunakan sebagai dasar untuk pengembangan bahan ajar yang akan dikembangkan.
Penelitian pendahuluan dilakukan melalui studi pustaka dan studi lapangan untuk menganalisis kebutuhan yang diperlukan untuk kepeluan pengembangan yang berdasarkan atas temuan fakta yang diperoleh dari observasi, wawancara dengan guru dan analisis kepustakaan. Penelitian ini diawali dengan penelitian pendahuluan yang dilakukan pada bulan Mei 2013 di SMP Negeri 3 Berbah.

Data yang diperoleh selama melakukan studi pustaka di SMP Negeri 3 Berbah dapat diketahui bahwa: (1) standar kompetensi dalam pembelajaran IPS Sejarah adalah siswa mampu memahami perkembangan masyarakat, kebudayaan, dan pemerintahan pada masa Islam di Indonesia, serta peninggalan-peninggalannya dengan baik. (2) bahan ajar yang digunakan siswa untuk pembelajaran IPS adalah buku yang ditebitkan dari Depdiknas yang berjudul "Mari Belajar IPS" yang terbit pada tahun 2010, (3) pembelajaran IPS di sekolah mempunyai jumlah standar kompetensi dan kompetensi dasar paling banyak jika dibandingkan dengan mata pelajaran lain, (4) bahan ajar yang digunakan siswa kurang menarik karena masih terlalu naratif.

Beberapa data yang diperoleh berdasarkan data studi lapangan melalui observasi dan wawancara, disimpulkan bahwa: (1) SMP Negeri 3 Berbah sudah memiliki laboratorium komputer yang layak digunakan untuk pembelajaran hanya saja jumlah komputer tidak sebanding dengan jumlah siswa yakni hanya memiliki 10 komputer, sedangkan jumlah siswa tiap kelas rata-rata berjumlah 32 siswa. Jumlah tersebut tidak memenuhi kebutuhsn siswa mendapat satu komputer. Perbandingan antara jumlah siswa dengan komputer yang tersedia menjadikan proses pembelajaran dengan menggunakan komputer tidak dapat berlangsung secara maksimal. Sehingga guru pengampu berpendapat jika pembelajaran akan lebih efektif jika dilakukan di dalam kelas. (2) bahan ajar dengan model mind map di sekolah tersebut belum dimanfaatkan untuk proses pembelajaran, (3) guru sudah pernah mengajar de- 
ngan menggunakan metode mind mapping dalam pembelajaran di kelas hanya saja belum mengembangkan bahan ajar dengan model mind map. Dengan adanya pengalaman guru mengajar dengan metode mind mapping tersebut maka memudahkan guru dalam menggunakan bahan ajar dengan model mind map yang dikembangkan. (4) materi IPS yang dibahas sangat padat, sedangkan guru mengajar hanya dengan metode ceramah sehingga terasa membosankan bagi siswa, (5) selama ini bahan ajar yang digunakan sudah cukup bagus hanya saja kurang menarik karena terlalu banyak materi, sehingga siswa merasa susah untuk menghafal materi, siswa menyarankan adanya media yang ringkas tetapi padat dan juga diperbanyak gambargambar yang menarik.

Produk Hasil Pengembangan

Bahan ajar yang dikembangkan dalam penelitian ini adalah bahan ajar cetak dengan model mind map pada pembelajaran IPS untuk siswa SMP. Dalam pengembangan bahan ajar ini menggunakan seperangkat alat yang digunakan, antara lain software pengolah gambar (Corel draw), software pengolah kata (Microsoft Word), serta software pembuat mind map (iMindMap 6.2.1).

Pengembangan bahan ajar ini mengacu pada silabus dan saran serta arahan dari guru mata pelajaran IPS di sekolah. Secara garis besar produk bahan ajar hasil pengembangan tahap awal berisi:

1. Kata pengantar, berisi kata pengantar dari penulis.

2. Pendahuluan, berisi deskripsi secara singkat mengenai metode mind mapping sebagai cara pengorganisasian pesan dalam bahan ajar.

3. Pedoman penggunaan, berisi deskripsi mengenai petunjuk belajar bagi siswa dalam menggunakan bahan ajar dengan model mind map.

4. Kompetensi, berisi Standar Kompetensi dan Kompetensi Dasar.

a. Standar Kompetensi: Siswa dapat memahami perkembangan masyara- kat sejak masa Hindu-Budha sampai masa kolonial Eropa.

b. Kompetensi Dasar: Siswa dapat memahami perkembangan masyarakat, kebudayaan, dan pemerintahan pada masa Islam di Indonesia, serta peninggalan-peninggalannya.

5. Peta konsep, berisi peta konsep materi "Perkembangan pada Masa Islam di Indonesia".

6. Materi:

a. Materi I, berisi: proses masuk dan berkembangnya agama dan kebudayaan Islam di Idonesia.

b. Materi II, berisi: kerajaan-kerajaan di Indonesia yang bercorak Islam.

c. Materi III, berisi: wujud akulturasi kebudayaan Indonesia dan kebudayaan Islam.

7. Latihan soal, soal terdiri dari 2 jenis, yaitu soal di tiap bab yang berbentuk soal mind map dan soal evaluasi diakhir materi berbentuk pilihan ganda dengan jumlah soal 30 butir.

8. Glosarium, berisi kumpulan definisi kata-kata yang sulit dipahami oleh siswa.

9. Rangkuman, berisi rangkuman materi dari awal sampai akhir materi secara singkat.

10.Daftar pustaka, berisi daftar buku atau referensi yang dijadikan acuan dalam mengembangkan bahan ajar.

11.Profil, berisi informasi mengenai biodata dari pengembang.

Adapun tampilan dari produk awal dapat dilihat pada gambar berikut:

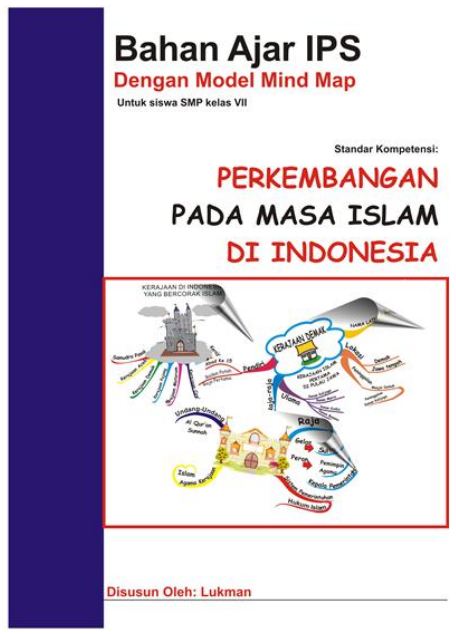

Gambar 2. Tampilan Cover Bahan Ajar. 
Sedangkan tampilan isi bahan ajar dapat dilihat pada gambar berikut:

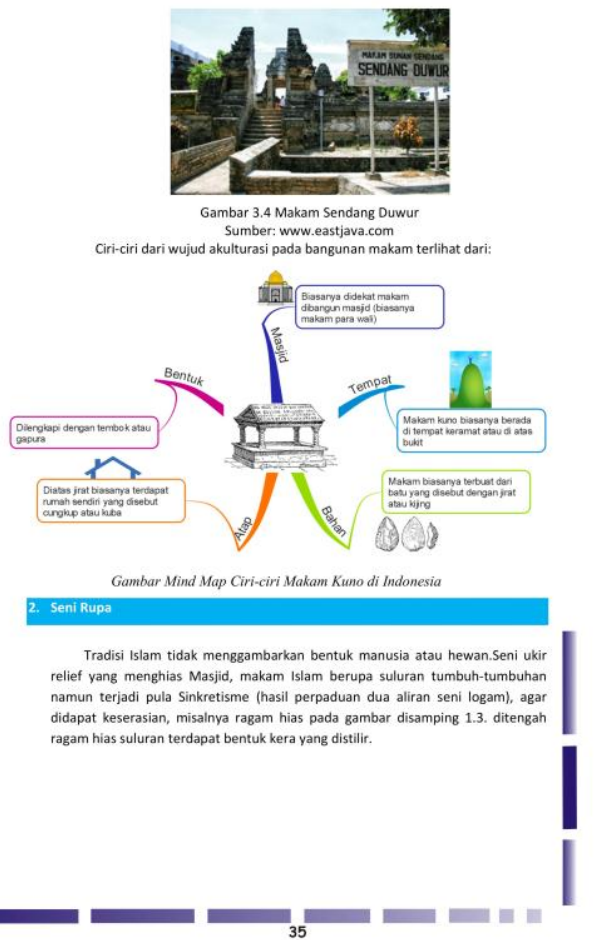

Gambar 3. Tampilan Isi Bahan Ajar

Hasil Validasi Ahli Materi

Validasi dilakukan oleh 4 orang ahli yang terdiri dari 2 orang ahli materi dan 2 orang ahli media. Ahli materi yang dijadikan sebagai validator materi pada produk bahan ajar dengan model mind map yaitu Dr. Aman sebagai ahli materi I yang merupakan salah satu dosen mata kuliah sejarah di Fakultas Ilmu Sosial, Universitas Negeri Yogyakarta dan Dr. Dyah Kumalasari yang juga merupakan salah satu dosen di Jurusan Sejarah Universitas Negeri Yogyakarta. Sedangkan validator ahli media yaitu Herman Dwi Surjono, Ph.D sebagai ahli media I yang merupakan dosen pengampu mata kuliah pengembangan media pembelajaran Universitas Negeri Yogyakarta dan Dr. Cristina Ismaniati sebagai ahli media II yang merupakan dosen di bidang Teknologi Pembelajaran.

Proses validari ahli materi dan ahli media dengan cara memberikan produk bahan ajar yang telah dikembangkan kepada masing-masing validator yang di- lengkapi dengan instrumen penilaian yang berupa angket skala likert yang mencakup aspek kelayakan isi materi dan aspek penyajian (untuk ahli materi) dan aspek bahasa dan gambar serta aspek kegrafisan (untuk ahli media).

Pelaksanaan validasi dengan cara validator membaca dan mengamati bahan ajar yang dikembangkan untuk masingmasing aspek serta memberikan penilaian dengan cara mengisi angket yang telah disediakan. Pada proses validasi, peneliti memperoleh data kuantitatif dan kualitatif yang sangat mendukung untuk pengembangan bahan ajar yang dikembangkan.

Validasi ahli materi dilakukan untuk mengetahui kualitas bahan ajar ditinjau dari aspek materi. Aspek yang dinilai meliputi aspek kelayakan isi dan aspek penyajian. Validasi dilakukan dengan cara memberikan produk bahan ajar hasil pengembangan untuk kemudian dinilai oleh ahli materi dengan angket skala 4 . Hasil penilaian ahli materi I dapat dilihat pada tabel 3 berikut:

Tabel 3. Rekap Rerata Skor Hasil Validasi Ahli Materi I

\begin{tabular}{cccc}
\hline No & Aspek Penilaian & Skor & Kategori \\
\hline 1 & Kelayakan Isi & 3,25 & Baik \\
2 & Penyajian & 3,33 & Sangat Baik \\
\hline Jumlah & 5,58 & \\
\hline Rata-rata & 3,29 & Sangat Baik \\
\hline
\end{tabular}

Adapun komentar dan saran dari ahli materi I yaitu memperbaiki cara penulisan daftar pustaka pada bagian akhir bahan ajar. Sedangkan hasil penilaian oleh ahli materi II dapat disajikan pada Tabel 4.

Tabel 4. Rekap Rerata Skor Hasil Validasi Ahli Materi II

\begin{tabular}{clcc}
\hline No & Aspek Penilaian & Skor & Kategori \\
\hline 1 & Kelayakan Isi & 2,87 & Baik \\
2 & Penyajian & 2,83 & Baik \\
\hline Jumlah & 5,7 & \\
\hline \multicolumn{2}{l}{ Rata-rata } & 2,85 & Baik \\
\hline
\end{tabular}

Adapun komentar dari ahli materi II yaitu: (1) sebaiknya lebih ditekankan 
keterkaitan antar materi dalam setiap pembahasan; (2) sebaiknya setiap memulai pokok bahasan diawali dengan apersepsi; (3) perbaiki penulisan daftar pustaka.

\section{Hasil Validasi Ahli Media}

Validasi dilakukan untuk mengetahui kualitas bahan ajar ditinjau dari aspek media. Dua aspek yang dinilai yaitu aspek bahasa dan gambar dan aspek kegrafisan. Penilaian dengan menggunakan angket 4 skala dengan jumlah 20 butir pertanyaan. Hasil penilaian ahli media I dapat dilihat pada tabel 5 berikut:

\section{Tabel 5. Rekap Rerata Skor Hasil Validasi} Ahli Media I

\begin{tabular}{cccc}
\hline No & Aspek Penilaian & Skor & Kategori \\
\hline 1 & Bahasa dan gambar & 3,66 & Sangat Baik \\
2 & Kegrafisan & 3,72 & Sangat Baik \\
Jumlah & 7,38 & \\
Rata-rata & 3,69 & Sangat Baik \\
\hline
\end{tabular}

Penilaian produk bahan ajar dari ahli materi II memberikan saran untuk melakukan revisi produk. Adapun saran dari ahli materi II sebagai berikut: (1) ukuran font pada halaman indikator diperbesar; (2) penempatan nomer halaman genap dan ganjil disesuaikan; (3) perbaiki format penulisan pada halaman ringkasan.

Sedangkan hasil penilaian ahli media II dapat dilihat pada tabel 6 berikut:

Tabel 6. Rekap Rerata Skor Hasil Validasi Ahli Media II

\begin{tabular}{llcc}
\hline No & Aspek Penilaian & Skor & Kategori \\
\hline 1 & Bahasa dan gambar & 3,11 & Baik \\
2 & Kegrafisan & 3,18 & Baik \\
Jumlah & 6,29 & \\
Rata-rata & 3,14 & Baik \\
\hline
\end{tabular}

Penilaian produk bahan ajar dari ahli materi II memberikan saran untuk melakukan revisi produk. Adapun saran dari ahli materi II sebagai berikut: (1) perbaiki tulisan dan ejaan yang salah ketik; (2) perbaiki penulisan paragraf yang ku- rang runtut dan efektif; (3) perbaiki penomeran gambar, ukuran gambar yang terlalu kecil, dan keterangan gambar.

1. Perbaiki gambar peta konsep.

Hasil Uji Coba Terbatas

Tujuan dari uji coba terbatas digunakan untuk mengumpulkan informasi yang dapat digunakan untuk memperbaiki produk dalam revisi berikutnya. Jumlah siswa dalam ujicoba terbatas berjumlah 9 siswa. Uji coba dilakukan dengan membagikan bahan ajar hasil pengembangan kepada siswa untuk dipelajari, selanjutnya siswa diminta untuk memberikan tanggapan mengenai kualitas produk dari segi teks dan gambar, kemenarikan, kepahaman, serta penyajian.

Rerata hasil penilaian siswa pada uji coba terbatas adalah 3,51 . Hasil penilaian ini menurut tabel konversi data kuantitatif ke data kualitatif skala 4 termasuk pada kriteria Sangat Baik. Ada 17 aspek penilaian yang dinilai oleh siswa. 14 aspek dinilai sangat baik dan 3 aspek dinilai baik. Secara rinci, dari 14 butir penilaian yang dinyatakan sangat baik adalah: 1) keterbacaan gambar, 2) kesesuaian gambar dengan materi, 3) kejelasan gambar, 4) kesesuaian ukuran gambar, 5) keterbacaan teks, 6) kesesuaian ukuran teks, 7) kemenarikan sampul, 8) kemenarikan tampilan isi, 9) kemenarikan warna, 10) kemudahan memahami materi, 11) kemudahan pemahaman konsep, 12) penyajian mind map, 13) kejelasan rangkuman, 14) kemudahan penggunaan glosarium.

Adapun ketiga aspek yang dinilai baik adalah: (1) keterangan gambar; (2) kemudahan penggunaan kalimat; (3) kemudahan penggunaan istilah.

Secara visual tampilan keseluruhan penilaian siswa pada uji coba terbatas terhadap bahan ajar dengan model mind map yang dikembangkan dapat disajikan pada Gambar 4. 


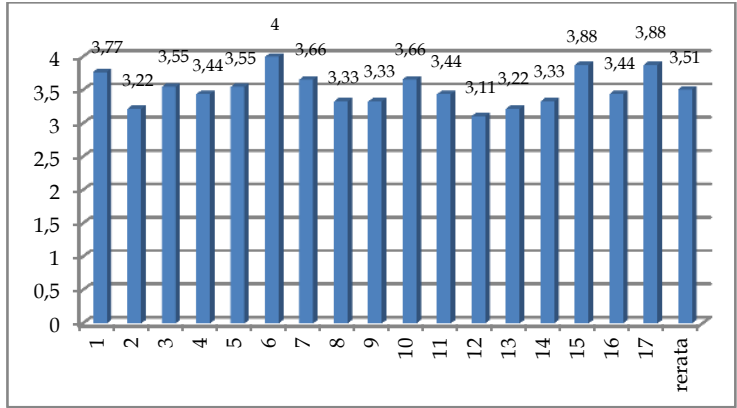

Gambar 4. Diagram Hasil Penilaian Siswa pada Uji Coba Terbatas

Berdasarkan uji coba terbatas, ada beberapa komentar dan saran yang ditulis oleh siswa mengenai bahan ajar dengan model mind map yang dikembangkan. Berikut komentar yang diungkapkan siswa, antara lain: (1) ukuran huruf lebih diperbesar dan glosarium ditambah karena masih banyak kata yang belum dimengerti; (2) cukup baik, mudah untuk dipahami, namun sedikit kurang ringkas, gambarnya jelas, mungkin bisa lebih kreatif lagi; (3) mind mapnya diperbanyak dan dibuat semenarik mungkin agar orang ingin membaca; (4) mudah dipahami tapi kurang ringkas; (5) ukuran font huruf lebih diperbesar dan gambar diperbanyak; (6) buku ini saya bisa lebih baik memahaminya dalam pembelajaran ini; (7) gambar mind map ada yang salah, tanggalan jawa dan hijriyah terbalik.

\section{Hasil Uji Coba Lapangan}

Tujuan uji coba lapangan untuk mengetahui apakah produk yang dihasilkan sudah memiliki kelayakan dan keefektifan produk dalam pembelajaran IPS. Uji coba lapangan pada kelas yang menggunakan bahan ajar hasil pengembangan dilakukan selama 4 kali pertemuan. Uji coba lapangan ditujukan untuk siswa kelas VII SMP Negeri 3 Berbah dengan jumlah subjek coba 31 orang siswa. Pada uji coba lapangan melibatkan kelompok kontrol yang menggunakan buku paket IPS sebagai pembanding atas kelompok yang menggunakan bahan ajar hasil pengembangan.
Pada tahap uji coba ini dilakukan dengan membagi bahan ajar dengan model mind map hasil untuk dipelajari siswa dalam proses pembelajaran. Uji coba diwali dengan pretes dan diakhiri dengan postes. Setelah siswa selesai belajar dengan menggunakan bahan ajar dengan model mind map, siswa memberikan tanggapan mengenai kualitas bahan ajar hasil pengembangan dengan mengisi angket yang telah disediakan. Penilaian diberikan oleh siswa mengenai kualitas produk dari segi teks dan gambar, kemenarikan, kepahaman, dan penyajian.

Rerata skor hasil penilaian siswa pada uji coba lapangan sebesar 3,47. Hasil penilaian ini menurut tabel konversi data kuantitatif ke data kualitatif skala 4 termasuk pada kriteria Sangat Baik. Terdapat 17 butir penilaian dan semua butir penilaian dinyatakan Sangat Baik. Secara rinci, dari 14 butir penilaian yang dinyatakan sangat baik adalah: 1) keterbacaan gambar, 2) kesesuaian gambar dengan materi, 3) keterangan gambar, 4) kejelasan gambar, 5) kesesuaian ukuran gambar, 6) keterbacaan teks, 7) kesesuaian ukuran teks, 8) kemenarikan sampul, 9) kemenarikan tampilan isi, 10) kemenarikan warna, 11) kemudahan memahami materi, 12) kemudahan penggunaan kalimat, 13) kemudahan penggunaan istilah, 14) kemudahan pemahaman konsep, 15) penyajian mind map, 16) kejelasan rangkuman, 17) kemudahan penggunaan glosarium.

Secara visual tampilan keseluruhan penilaian siswa pada uji coba lapangan terhadap bahan ajar dengan model mind map yang dikembangkan dapat disajikan pada Gambar 5.

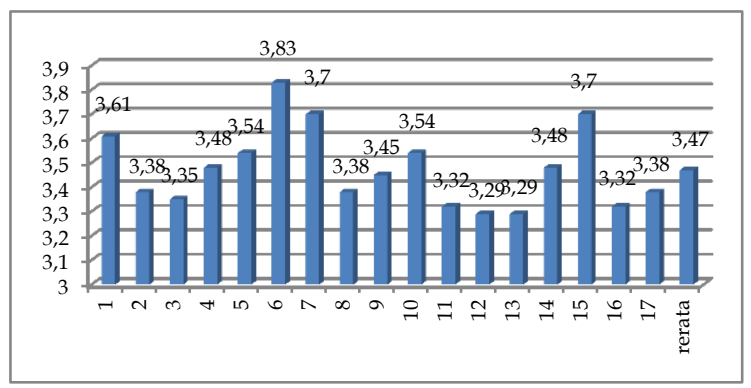

Gambar 5. Diagram Hasil Penilaian Siswa pada Uji Coba Lapangan 
Berdasarkan uji coba lapangan yang dilakukan, hasil angket yang diisi oleh siswa memberikan beberapa komentar dan saran mengenai bahan ajar dengan model mind map hasil pengembangan. Berikut komentar yang diungkapkan siswa, antara lain: (1) isi buku ini sudah cukup baik dan saya juga sudah mulai bisa memahami isi buku ini; (2) seharusnya diberi gambar-gambar kecil/bingkai; (3) gambarnya menarik, warna serasi, dan konsepnya cocok; (4) bukunya menarik dan dapat menambah daya tarik membaca; (5) mudah dipahami; (6) buku ini saya bisa lebih baik memahaminya dalam pembelajaran.

\section{Hasil Uji Coba Keefektifan Produk}

Uji coba keefektifan dilakukan untuk mengetahui keefektifan produk hasil pengembangan dalam pembelajaran IPS dengan melihat peningkatan gain skor dan ketuntasan belajar siswa mengenai materi "Perkembangan pada Masa Islam di Indonesia", ketuntasan belajar siswa dilihat dari sebelum dan setelah menggunkan bahan ajar dengan model mind map yang dikembangkan. Kriteria Ketuntasan Minimal (KKM) untuk mata pelajaran IPS di SMP Negeri 3 berbah adalah 7,00.

Pembelajaran dengan menggunakan bahan ajar dengan model mind map ini dilakukan pada tangga 1 juni 2013 sampai dengan 1 juli 2013 di SMP Negeri 3 Berbah yang diikuti oleh 31 siswa pada kelas eksperimen dan 31 siswa pada kelas kontrol. Kelas VII C yang ditetapkan sebagai kelas kontrol yakni kelas yang menggunakan bahan ajar cetak yang tidak menggunakan mind map, dan kelas VII B sebagai kelas eksperimen yakni kelas yang menggunakan bahan ajar dengan model mind map yang dikembangkan. Penggunaan bahan ajar dengan model mind map hasil pengembangan pada kelas eksperimen meliputi pelaksanaan pretes sebelum pembelajaran dimulai, kemudian dilanjutkan dengan pelaksanaan pembelajaran menggunakan bahan ajar dengan model mind map, dan diakhiri dengan postes.
Adapun siswa kelas VII yang mengikuti pretes dan postes berjumlah 62 orang dengan rincian 31 siswa kelompok kontrol dan 31 siswa kelompok eksperimen. Berdasarkan hasil pretes dan postes pada kelas kontrol dan kelas eksperimen dapat diketahui nilai pada masing-masing kelas tersebut yakni nilai tertinggi, nilai terendah, rerata dan selisih postes-pretes (N-Gain Score). Rekap hasil uji pretes dan postes tersebut disajikan pada Tabel 7.

Tabel 7. Rekap Hasil Skor Siswa

\begin{tabular}{llcccc}
\hline \multirow{2}{*}{ No Nilai } & \multicolumn{4}{c}{ Kelas } \\
\cline { 3 - 6 } & & \multicolumn{3}{c}{ Kontrol } & \multicolumn{3}{c}{ Eksperimen } \\
\cline { 2 - 5 } & Pretes & Postes & Pretes & Postes \\
\hline 1 & Nilai Terendah & 53 & 70 & 53 & 70 \\
2 & Nilai Tertinggi & 86 & 93 & 86 & 96 \\
3 & Rata-Rata & 69,19 & 79,45 & 69,87 & 83,74 \\
4 & Indeks Gain & \multicolumn{2}{c}{0,35} & 0,45 \\
5 & Gain & \multicolumn{2}{c}{ Sedang } & \multicolumn{2}{c}{ Sedang } \\
\hline
\end{tabular}

Selisih nilai pretes dan postes kelas kontrol ditunjukan pada nilai Gain Score dapat divisualisasikan pada Gambar 6.

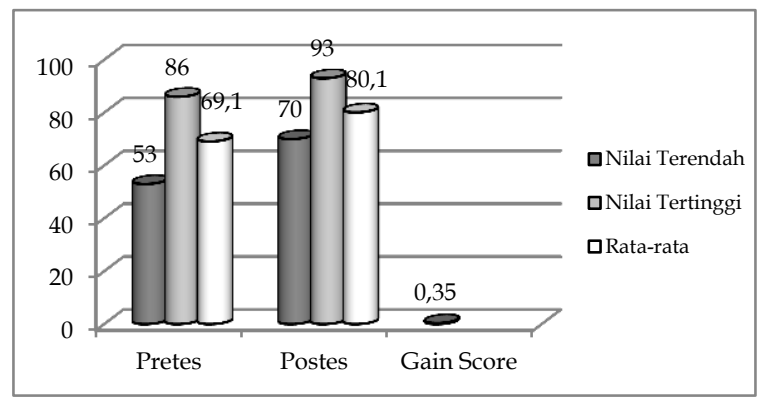

Gambar 6. Diagram Nilai Gain Score pada Kelas Kontrol

Sedangkan selisih antara nilai pretes dan postes pada kelas eksperimen ditunjukan pada nilai gain score dapat divisualisasikan pada Gambar 7.

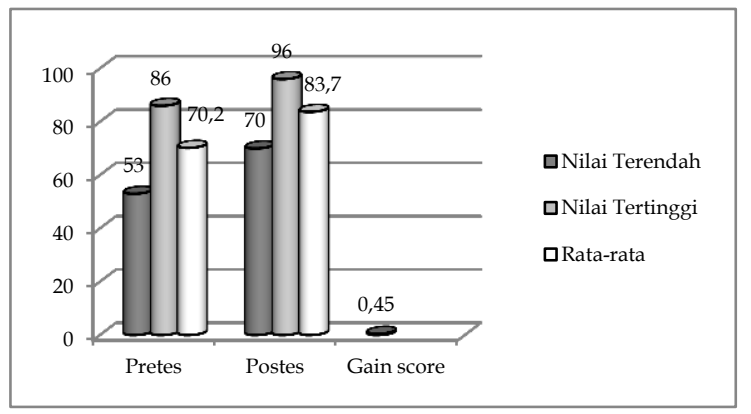

Gambar 7. Diagram Nilai Gain Score Kelas Eksperimen 
Berdasarkan gambar 6 dan 7 dapat diketahui bahwa terdapat perbedaan nilai gain score pada masing-masing kelas. Pada kelas kontrol diperoleh gain score sebesar 0,35 . Nilai tersebut berdasarkan klasifikasi nilai gain berada pada klasifikasi sedang. Sedangkan pada kelas eksperimen diperoleh nilai gain score sebesar 0,45 dengan klasifikasi sedang.

Ketuntasan belajar siswa mengacu pada KKM mata pelajaran IPS di SMP N 3 berbah yaitu $\geq 70$. Pada pretes kelas yang menggunakan bahan ajar dengan model mind map terdapat $20(64,5 \%)$ siswa dinyatakan tuntas sedangkan $11 \quad(35,4 \%)$ siswa dinyatakan tidak tuntas. Sedangkan pada saat postes siswa yang dinyatakan tuntas sebesar $100 \%$. Ketuntasan belajar siswa pada kelas kontrol disajikan pada Gambar 8.

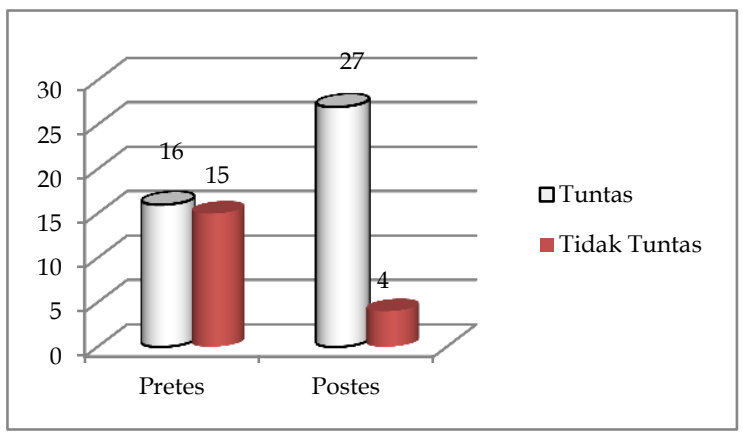

Gambar 8. Diagram Ketuntasan Belajar Siswa Kelas Kontrol

Sedangkan ketuntasan belajar siswa pada saat pretes dan postes pada kelas eksperimen pada saat uji coba lapangan disajikan pada Gambar 9.

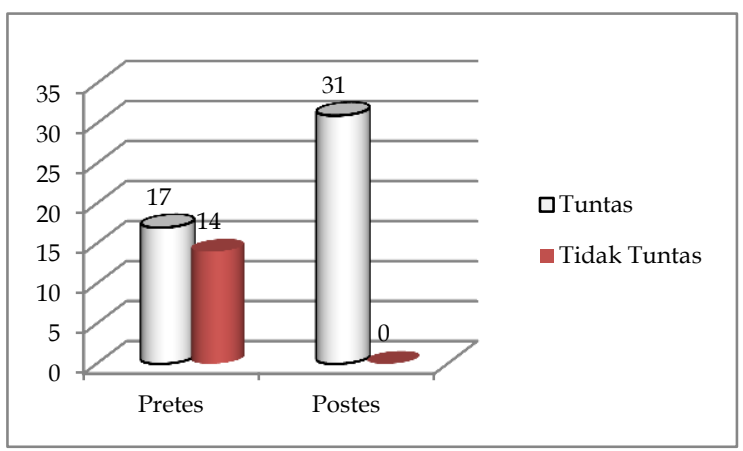

Gambar 9. Diagram Ketuntasan Belajar Siswa Kelas Eksperimen
Berdasarkan data yang diperoleh, maka dapat disimpulkan bahwa bahan ajar dengan model mind map efektif digunakan dalam proses pembelajaran IPS pada siswa SMP N 3 Berbah. Hal tersebut terbukti berdasarkan perolehan nilai gain skor serta ketuntasan belajar siswa setelah menggunakan bahan ajar hasil pengembangan. Hasil ini membuktikan bahwa bahan ajar dengan model mind map yang dikembangkan efektif digunakan untuk pembelajaran IPS.

Produk bahan ajar dikembangkan melalui beberapa tahap pengembangan, yaitu: studi pendahuluan, pengembangan produk awal, uji coba terbatas, revisi, uji coba lapangan, revisi, hingga akhirnya menghasilkan produk final. Tujuan dari penelitian ini yaitu untuk mengetahui kelayakan serta keefektifan bahan ajar yang dikembangkan pada pembelajaran IPS.

Bentuk akhir dari produk yang dikembangkan adalah bahan ajar cetak dengan model mind map yang berbentuk buku. Bahan ajar ini dikembangkan dengan menggunakan software iMindMap 6.2.1 untuk membuat gambar-gambar mind map. Bahan ajar ini memuat materi "Perkembangan Pada Masa Islam di Indonesia" pada mata pelajaran Ilmu Pengetahuan Sosial (IPS) untuk siswa SMP yang terdiri dari tiga bab utama mengenai 1) proses masuk dan berkembangnya agama Islam di Indonesia, 2) kerajaan-kerajaan di Indonesia yang bercorak Islam, 3) wujud akulturasi kebudayaan Indonesia dan kebudayaan Islam. Adapun komponen-komponen dari bahan ajar ini antara lain: cover, kata pengantar, pendahuluan, materi, rangkuman, glossarium, soal-soal latihan dan daftar pustaka.

Pengorganisasian pesan dalam bahan ajar ini dikembangan dengan model mind map yang disusun secara sistematis sehingga memudahkan siswa untuk memahami materi dengan baik. Penggunaan mind map dalam bahan ajar ini dapat memudahkan siswa dalam memahami materi. Hal itu terbukti dari hasil postes siswa pada kelompok eksperimen yang mengalami kenaikan lebih besar jika dibanding- 
kan dengan kelompok kontrol yang menggunakan bahan ajar buku paket yang tidak menggunakan mind map dalam pengorganisasian isi materinya.

Proses pengembangan bahan ajar ini mengikuti tahap-tahap dalam pengembangan dan juga telah selesai divalidasi oleh ahli materi dan ahli media. Berdasarkan penilaian dari ahli materi dan ahli media, bahan ajar ini layak digunakan sebagai sumber belajar.

Bahan ajar ini sebetulnya didesain untuk pembelajaran individu, namun tidak menutup kemungkinan siswa dapat menggunakannya dalam pembelajaran kelompok. Peran guru sebagai fasilitator belajar dapat memberikan penjelasan-penjelasan untuk membantu mempercepat siswa dalam memahami materi yang ada di dalam bahan ajar ini. Maka produk ini dapat digunakan sebagai alat bantu guru dalam proses pembelajaran agar dapat meningkatkan prestasi belajar siswa yang ditinjau dari aspek kognitif siswa.

Karakteristik dari bahan ajar dengan model mind map hasil pengembangan ini merupakan keunggulan yang dimilikinya. Keunggulan tersebut antara lain: (1) penyajian materi menggunakan gambargambar mind map yang dapat memperkuat kognisi siswa sehingga memudahkan siswa dalam memahami materi; (2) adanya sajian gambar yang bervariasi membuat bahan ajar dengan model mind map ini menarik dan disenangi oleh siswa 3) bahan ajar ini berbentuk media cetak yaitu buku sehingga sangat mudah digunakan oleh siswa tanpa harus memiliki keterampilan khusus, 4) disusun dengan menggunakan kaidah-kaidah penulisan bahan ajar, 5) terdapat umpan balik di dalamnya, 6) dapat digunakan siswa sebagai sumber belajar mandiri maupun kelompok.

Selain keunggulan, terdapat beberapa kelemahan yang dimiliki oleh bahan ajar hasil pengembangan, yaitu (1) materi pada bahan ajar ini hanya memuat bidang kajian sejarah, belum mengkaji IPS secara terpadu; (2) keterbatasan cakupan materi hanya membahas materi "Perkembangan pada Masa Islam di Indonesia"; (3) kemam- puan siswa untuk menangkap informasi yang bersifat visual, karena siswa mempunyai gaya belajar yang berbeda-beda.

Bahan ajar dengan model mind map ini dikembangkan sebagai media guru dalam proses pembelajaran, agar menciptakan pembelajaran yang kreatif dan inovatif sehingga dapat meningkatkan pemahaman siswa mempelajari materi yang diajarkan. Bagi siswa bahan ajar dengan model mind map ini merupakan suplemen materi yang dipelajari di sekolah.

\section{Simpulan dan Saran}

Simpulan

Berdasarkan pada hasil penelitian dan pengembangan bahan ajar dengan model mind map ini, dapat disimpulkan sebagai berikut.

Pertama, produk ini layak digunakan dalam pembelajaran berdasarkan penilaian dari ahli materi dan ahli media yang ditinjau dari aspek kelayakan isi, aspek kelayakan penyajian, aspek bahasa dan gambar dan aspek kegrafisan dengan rerata skor 3,24 dengan kategori Baik dan rerata skor dari keseluruhan uji coba sebesar 3,49 dengan kategori Baik.

Kedua, bahan ajar hasil pengembangan ini efektif untuk digunakan sebagai sumber belajar. Hal tersebut terlihat pada saat uji keefektifan penggunaan bahan ajar pada siswa setelah menggunakan bahan ajar dengan model mind map. Hasil dari tes menunjukan bahwa peningkatan skor postes pada kelas eksperimen sebesar 13,87\% dengan nilai gain score sebesar 0,45 dengan klasifikasi sedang, dan persentase ketuntasan siswa mencapai $100 \%$. Sedangkan kelas kontrol yang menggunakan buku cetak IPS dengan peningkatan skor postes 10,26\% dengan nilai gain score 0,35 berada pada klasifikasi sedang, dan persentase ketuntasan $87,1 \%$. Hasil tersebut menunjukan bahwa kelas yang menggunakan bahan ajar dengan model mind map lebih baik dari pada kelas yang menggunakan buku paket IPS. 


\section{Saran Pemanfaatan}

Bagi guru, pemanfaatan bahan ajar dengan model mind map ini akan efektif hasilnya jika guru dapat menggunakannya dengan cara yang tepat. Saran pemanfaatan dalam menggunakan produk bahan ajar ini yaitu sebagai berikut: (1) Guru hendaknya menjelaskan terlebih dahulu kepada siswa tentang mind map, fungsi mind map, cara kerja mind map, dan juga cara membuat mind map. Sehingga siswa terbiasa untuk memahami materi yang disajikan menggunakan mind map; (2) dalam proses pembelajaran guru dapat menyampaikan materi dalam bahan ajar ini dengan cara menjelaskan dan mengajak diskusi kepada siswa. Guru diharapkan dapat memberikan tugas kepada siswa untuk membuat rangkuman materi dalam bentuk mind map. Hal ini diperlukan untuk mengasah kemampuan siswa mengingat materi yang telah disampaikan.

Bagi siswa, agar pemanfaatan bahan ajar dengan model mind map ini dapat efektif maka hendaknya untuk mengikuti saran-saran sebagai berikut: (a) Siswa hendaknya membaca dan mempelajari keseluruhan materi dalam bahan ajar ini dengan baik. Diskusikan dengan guru dan teman apabila terdapat materi yang belum dimengerti; (b) siswa hendaknya berlatih untuk terbiasa menggambar mind map. Hal ini diperlukan untuk mengasah daya ingat siswa mengenai materi yang telah dipelajari.

\section{Diseminasi}

Penyebarluasan bahan ajar ini dapat melalui sekolah untuk dapat dipakai sebagai salah satu sumber belajar untuk siswa. Bahan ajar dengan model mind map ini juga dapat didiseminasikan melalui MGMP (Musyawarah Guru Mata Pelajaran) ataupun secara elektronik melalui media internet yang dapat diunduh dan dicetak bagi siapa saja yang membutuhkan. Selain itu dapat juga disampaikan melalui seminar-seminar yang relevan.
Pengembangan Produk Lebih Lanjut

Penelitian dan pengembangan lebih lanjut hendaknya untuk dapat memperhatikan kebutuhan siswa. Sehingga produk yang dikembangkan dapat membantu dan memberikan kontribusi besar dalam meningkatkan pemahaman konsep siswa sehingga dapat menghilangkan pemikiran siswa bahwa belajar IPS sulit karena terlalu banyak hafalan dan bahan ajarnya tidak menarik.

Untuk hasil yang lebih maksimal pada pengembangan produk lebih lanjut agar dapat menambahkan kelengkapan komponen yang belum tersedia seperti menu refleksi, selain itu juga untuk dapat menambahkan gambar mind map dengan tampilan 3D sehingga gambar-gambar mind map tampak lebih menarik dan lebih dinamis. Pengembangan produk lebih lanjut juga diharapkan dapat manambahkan cakupan materi yang lebih luas yang memungkinkan untuk dikembangkan. Sehingga cakupan materi tidak sebatas pada materi-materi secara parsial, akan tetapi dapat memuat materi IPS secara terpadu.

\section{Daftar Pustaka}

AECT. (2004). AECT definition and terminology committee document: the meanings of educational technology.

Borg, W.R. \& Gall, M.D. (1983). Educational research. An introduction. New York: Longman.

Buzan. T. (2005). How to mind map: Mind map untuk meningkatkan kreativitas. (Terjemahan Eric Suryaputra). Jakarta: Gramedia.

Buzan, T., \& Buzan, B. (1996). The mind map book: How to use radiant thinking to maximize your brain's untapped potential. New York: Plume.

DePorter \& Hernacki. (2011). Quantum learning; Membiasakan Belajar Nyaman dan Menyenangkan. (Terjemahan Alwiyah Abdurrahman). Bandung: Khaifa. 
Hake, R. R. (1998). Interactive-engagement vs traditional methods: A sixthousand-student surveyof mechanicstest data for introductory physics course. The American Journal of Physics Research 66, 64-74.

Januszewski, A. \& Molenda, M. (2008). Educational technology; A definition with commentary. New York: Taylor and Francis Group.
Miarso, Y. (2004). Menyemai benih teknologi pendidikan. Jakarta: Kencana.

Saleh, A. (2008). Kreatif mengajar dengan mind map. Bandung: Tinta Emas Publishing.

Sapriya. (2011). Pendidikan IPS; konsep dan pembelajaran. Bandung: Remaja Rosdakarya. 